\title{
Endogeic earthworms shape bacterial functional communities and affect organic matter mineralization in a tropical soil
}

\author{
Laetitia Bernard ${ }^{1}$, Lydie Chapuis-Lardy ${ }^{2}$, Tantely Razafimbelo ${ }^{3}$, Malalatiana \\ Razafindrakoto $^{3}$, Anne-Laure Pablo ${ }^{1}$, Elvire Legname ${ }^{1}$, Julie Poulain ${ }^{4}$, Thomas Brüls ${ }^{4}$, \\ Michael O’Donohue ${ }^{5}$, Alain Brauman ${ }^{1}$, Jean-Luc Chotte ${ }^{1}$ and Eric Blanchart ${ }^{1}$ \\ ${ }^{1}$ Institut de Recherche pour le Développement (IRD), UMR Eco\&Sols, Montpellier Cedex, France; ${ }^{2}$ Institut de \\ Recherche pour le Développement (IRD), UMR Eco\&Sols, Antananarivo, Madagascar; ${ }^{3}$ Université \\ d'Antananarivo, Laboratoire des Radio-Isotopes (LRI), Antananarivo, Madagascar; ${ }^{4}$ Institut de Génomique, \\ Genoscope, UMR8030 (CNRS, CEA, Université d'Evry), Evry, France and ${ }^{5}$ INSA, LISBP, Toulouse Cedex,
}

France

\begin{abstract}
Priming effect (PE) is defined as a stimulation of the mineralization of soil organic matter (SOM) following a supply of fresh organic matter. This process can have important consequences on the fate of SOM and on the management of residues in agricultural soils, especially in tropical regions where soil fertility is essentially based on the management of organic matter. Earthworms are ecosystem engineers known to affect the dynamics of SOM. Endogeic earthworms ingest large amounts of soil and assimilate a part of organic matter it contains. During gut transit, microorganisms are transported to new substrates and their activity is stimulated by (i) the production of readily assimilable organic matter (mucus) and (ii) the possible presence of fresh organic residues in the ingested soil. The objective of our study was to see (i) whether earthworms impact the PE intensity when a fresh residue is added to a tropical soil and (ii) whether this impact is linked to a stimulation/inhibition of bacterial taxa, and which taxa are affected. A tropical soil from Madagascar was incubated in the laboratory, with $a^{13} \mathrm{C}$ wheat straw residue, in the presence or absence of a peregrine endogeic tropical earthworm, Pontoscolex corethrurus. Emissions of ${ }^{12} \mathrm{CO}_{2}$ and ${ }^{13} \mathrm{CO}_{2}$ were followed during 16 days. The coupling between DNA-SIP (stable isotope probing) and pyrosequencing showed that stimulation of both the mineralization of wheat residues and the PE can be linked to the stimulation of several groups especially belonging to the Bacteroidetes phylum.
\end{abstract}

The ISME Journal (2012) 6, 213-222; doi:10.1038/ismej.2011.87; published online 14 July 2011

Subject Category: microbial ecology and functional diversity of natural habitats

Keywords: Bacteroidetes; DNA-SIP; Madagascar; Pontoscolex corethrurus; priming effect; pyrosequencing

\section{Introduction}

Soil microorganisms convert fresh organic matter (FOM) entering the soil into chemically stable, biologically inactive organic matter via the so-called humification process (Brookes et al., 2008). This process is comprised of discrete steps, during which the organic matter is exposed to microbial activity. At each successive step, more energy is required to breakdown the structures, which become progressively more complex and disordered, but richer in organic $\mathrm{N}$ and P. Moreover, microorganisms usually mineralize $40-60 \%$ of the carbon contained within

Correspondence: L Bernard, Institut de Recherche pour le Développement (IRD), UMR Eco\&Sols, 2 place Viala Bt12, Montpellier Cedex 1, F-34060, France.

E-mail: laetitia.bernard@ird.fr

Received 7 March 2011; revised 6 June 2011; accepted 6 June 2011; published online 14 July 2011 the organic matter as $\mathrm{CO}_{2}$. Therefore, soil organic matter (SOM) is a continuum of organic molecules, corresponding to the various intermediates of the FOM to biologically inactive organic matter conversion process.

The apparent linearity of the humification process is sometimes disturbed by a mechanism called priming effect (PE). PE is defined as a change in the decomposition rate of the SOM provoked by the addition of FOM (Jenkinson, 1966; Blagodatskaya and Kuzyakov, 2008). The positive PE (stimulation of the SOM mineralization rate) leads to the recycling of the nutrients (organic $\mathrm{N}$ and $\mathrm{P}$ ) trapped in the SOM and benefits the primary production (Kuzyakov et al., 2000). On the other hand, when the $\mathrm{PE}$ is unbalanced by the humification process, the decrease in SOM content may render the soil more sensitive to erosion processes. The PE was first described many years ago by Löhnis (1926), but 
nevertheless this process is still poorly understood (Guenet et al., 2010). Understanding and controlling this process is a key concern in developing countries, where organic matter of local origin is used to reduce mineral fertilizer input (Beare et al., 1997) and where high temperatures accelerate microbial metabolism and $\mathrm{C}$ turnover rates.

Two different mechanisms have been proposed to explain the true positive PE. The first one describes the $\mathrm{PE}$ as an indirect result of an increase in extracellular FOM-degrading enzymes produced by microorganisms (Kuzyakov et al., 2000). The second, proposed by Fontaine et al. (2003), suggests that the SOM-degrading microbial population might out-compete the FOM decomposers with regard to the metabolism of polymeric FOM compounds. Likewise, using the energy-rich FOM, SOM feeders would increase the decomposition rate of the nutrient-rich SOM in a co-metabolism process, which would allow them to assimilate $\mathrm{N}$ and $\mathrm{P}$. These authors concluded that any disturbances affecting the relative proportions of the two functional groups (FOM and SOM feeders) would impact the intensity of the PE. However, the identity of microorganisms that form part of the SOM-feeder group remains more or less unknown (Bernard et al., 2009; Kuzyakov, 2010).

Ecosystem engineers are organisms that modulate the availability of resources to other species, by causing physical changes in biotic or abiotic material (Jones et al., 1994). It is well known that earthworms modify the environment of soil microorganisms (Lavelle, 1997). Earthworms provide labile FOM, present in their mucus, and increase decomposition by favoring the contact between microorganisms and their substrates, via the mixing effect of gut transit. Moreover, earthworms alter edaphic parameters, such as soil structure, $\mathrm{pH}, \mathrm{O}_{2}$, water regime etc. Basically, from a short-term perspective, earthworms have been shown to stimulate the rates of decomposition and mineralization of SOM (Speratti and Whalen, 2008), while in the longer term they increase the incorporation of fresh residues into newly formed stable microaggregates within casts, thus promoting carbon storage (Bossuyt et al., 2004, 2006; Coq et al., 2007; and for review see Brown et al., 2000). Additionally, it has been shown that while earthworms are unlikely to possess an indigenous microbial community, they significantly impact the structure of the soil microbial community (Egert et al., 2004).

Regarding the different functional traits that have been attributed to earthworms, it is pertinent to ask (i) whether earthworms can alter the intensity of the PE generated by the addition of fresh crop residues to soil and (ii) whether such an impact can be linked to a shift in the balance between FOM and SOM feeders, as suggested by Fontaine et al. (2003). To answer these questions, a tropical soil sample from Madagascar, amended with highly ${ }^{13} \mathrm{C}$-enriched, finely ground wheat straw was incubated in laboratory conditions in the presence or absence of a peregrine (found on most continents) endogeic (geophagous) tropical earthworm, Pontoscolex corethrurus (Oligochaeta, Glossoscolecidae). Emissions of ${ }^{12} \mathrm{CO}_{2}$ (soil-derived respiration) and ${ }^{13} \mathrm{CO}_{2}$ (residuebased respiration) were monitored over a 16-day period and microbial genomic DNA was extracted at the end of the experiment, after earthworms had ingested the whole soil. To identify bacterial populations that are either stimulated or inhibited by earthworms and to relate these to functional groups (FOM feeders, SOM feeders, FOM and SOM co-metabolizers), DNA-SIP (stable isotope probingseparation between ${ }^{12} \mathrm{C}$ - and ${ }^{13} \mathrm{C}$-enriched DNA) was combined with $16 \mathrm{~S}$ rRNA gene sequence analysis, which was performed on both ${ }^{12} \mathrm{C}$ and ${ }^{13} \mathrm{C}$ DNA fractions arising from experiments conducted in the presence or absence of earthworms.

\section{Materials and methods}

Wheat cultivation and labeling

Wheat straw labeled with ${ }^{13} \mathrm{C}(95 \%)$ was obtained from the CEA (Commissariat à l'Energie Atomique, Cadarache, France). Growth and labeling were achieved as described by Bernard et al. (2007). After harvesting, the straw was oven-dried at $65^{\circ} \mathrm{C}$ and milled in a bead beater to obtain a powder.

\section{Collection of earthworms}

P. corethrurus, an endogeic earthworm species, commonly found in tropical soils, was used in the experiment. Individuals were collected in Madagascar, on terrain under Aristida sp. grassland, in the vicinity of Antsirabe in the Malagasy Highlands $\left(19^{\circ} 47^{\prime} \mathrm{S}, 47^{\circ} 06^{\prime} \mathrm{E}, 1600 \mathrm{~m}\right.$ above sea level). Forty-eight adults were selected and introduced into a sample of the experimental soil, where they remained for 3 days for acclimation. Afterwards, 24 earthworms were transferred to an identical soil, amended with ${ }^{13} \mathrm{C}$ labeled wheat straw $\left(0.5 \mathrm{mgg}^{-1}\right.$ dried soil) and the acclimation period was pursued for further 2 days, before the beginning of the experiment.

\section{Soil microcosms set up}

The experimental site was located in Madagascar, near Antananarivo $\left(18^{\circ} 46^{\prime} \mathrm{S}, 47^{\circ} 32^{\prime} \mathrm{E}\right)$. The soil studied was Ferralsol (FAO, 1998) under grassland dominated by Aristida sp. Soil texture consisted of $38 \%$ sand $(50-2000 \mu \mathrm{m}), 16 \%$ silt $(2-50 \mu \mathrm{m})$ and $46 \%$ clay $(0-2 \mu \mathrm{m})$. The surface soil $(0-10 \mathrm{~cm})$ contained $16.2 \mathrm{mg}$ organic $\mathrm{Cg}^{-1}$ soil, $1 \mathrm{mg}$ total $\mathrm{Ng}^{-1}$ soil, $3.3 \mu \mathrm{g} \mathrm{g}^{-1}$ soil, with a $\mathrm{pH}$ of 5.2 in water. Microcosms were set up by placing $100 \mathrm{~g}(\mathrm{dw})$ of $2 \mathrm{~mm}$ sieved soil into $250 \mathrm{ml}$ plasma flasks. Soil samples were supplemented with sterile water to reach $100 \%$ of the water holding capacity. Four experiments were set up: control (CT), composed exclusively of the soil sample; straw-amended soil 
(ST), composed of soil and ${ }^{13} \mathrm{C}$-labeled milled wheat straw; worm-inoculated soil (WT), composed of soil and worms; and a combination of ST and WT (SWT), which contained all components. All of the soil microcosms were incubated in the dark at $28^{\circ} \mathrm{C}$ in open flasks for 16 days, with regular (every 2 days) monitoring of soil water content, in order to ensure optimal biological conditions. The experiment was ended after 16 days, once all of the soil sample in the microcosms had been transited through the earthworm gut, that is when the whole soil has been transformed into worm casts.

\section{Total and ${ }^{13} \mathrm{C}-\mathrm{CO}_{2}$ measurements}

To periodically analyze respiration in the microcosm experiments (after 0, 1, 3, 7, 10 and 16 days of incubation), the flasks were temporarily closed (90 min) with a gas-tight septum. The gaseous headspace was then sampled using gas-tight syringes and analyzed for $\mathrm{CO}_{2}$ on a Varian 3900 gas microchromatographer (Varian Inc., Palo Alto, CA, USA). After day 16, upon removal of the earthworms from the microcosm, they were placed on wet cotton paper over night (to empty gut contents) and then pooled in soil-free sealed flasks. Their respiration $\left(\mathrm{CO}_{2}\right.$ quantification) was analyzed as described previously. Hourly fluxes were calculated assuming a linear increase in gas concentration in the microcosm and bottle headspace with time.

In the case of the experiments containing ${ }^{13} \mathrm{C}$-labeled straw (ST and SWT), the gas phases were also analyzed with regard to carbon isotopic enrichment. These analyses were performed after 0, 3, 7 and 16 days by transferring samples of the microcosm experiments to Exetainer screw capped tubes (Labco Ltd, High Wycombe, UK), which were sealed with silicone before the analysis. Carbon isotopic enrichment analyses were performed on a GC-IRMS (gas chromatographer coupled to an isotope ratio mass spectrometer) equipped with Roboprep G and Tracermass modules (SerCon Ltd, Crewe, UK). For analyses, ${ }^{13} \mathrm{C}$-enriched $\mathrm{CO}_{2}$ were first diluted in a known concentration of pure $\mathrm{CO}_{2}$, before separating and quantifying the different $\mathrm{CO}_{2}$ species $(44,45$ and $46 \mathrm{~g} \mathrm{~mol}^{-1}$ ). Taking into account the fact that the milled wheat straw was $95 \%{ }^{13} \mathrm{C}$-enriched, measured ${ }^{13} \mathrm{CO}_{2}$ values were corrected to extract the value for straw-derived ${ }^{13} \mathrm{CO}_{2}$. To calculate the quantity of ${ }^{12} \mathrm{CO}_{2}$ release attributable to the PE (that is wheat straw-induced stimulation of SOM mineralization) the following formulas were applied:

${ }^{12} \mathrm{CO}_{2}$ release attributable to the PE $(\mathrm{ST})=$ total $\mathrm{CO}_{2}$ (ST)-total $\mathrm{CO}_{2}$ (CT)-straw-derived $\mathrm{CO}_{2}$ (ST)

${ }^{12} \mathrm{CO}_{2}$ release attributable to the PE $(\mathrm{SWT})=$ total $\mathrm{CO}_{2}$ (SWT)-total $\mathrm{CO}_{2}$ (W)-straw-derived $\mathrm{CO}_{2}(\mathrm{~W})-$ total $\mathrm{CO}_{2}$ (WT)-straw-derived $\mathrm{CO}_{2}$ (SWT), where W is earthworm respiration registered at $\mathrm{t} 16 \mathrm{~d}$ as described previously. Earthworm respiration was considered stable along time, because only adults were used and their weight did not change across the experiment. A schematic histogram explaining the way $\mathrm{CO}_{2}$ from different origins are measured or calculated is presented in Supplementary Figure S1.

Earthworm-related effects on soil respiration, straw mineralization and the PE were evaluated using a derivative of the RII index (Armas et al., 2004), which varies between -1 and +1 and has median value of 0 . This index is calculated as follows: $I=(A-B) /(A+B)$, where $A$ and $B$ are the $\mathrm{CO}_{2}$ values measured either in the CT and the WT treatment, respectively (for soil respiration), or in the ST and SWT (for straw mineralization and PE).

DNA extraction from soil

DNA from the original soil or from the four microcosm experiments, sampled at day 16 , were extracted using the procedure described by Bernard et al. (2007) with slight alterations. The principle difference was the use of a Fast Prep cell tissue homogeneizer, associated with the lysing matrix E for soil (MP Biomedicals, Illkirch, France). The protocol is detailed in Supplementary Information.

Isopycnic centrifugation and fractionation

Density gradient centrifugation was performed in $8.9 \mathrm{ml}$ polyallomer Optiseal tubes (Beckman, Krefeld, Germany) using a 70.1-Ti fixed-angle rotor (Beckman, Nyon, Switzerland). Because the coupling of DNA-SIP and pyrosequencing approach is heavy to perform, purified DNA samples, extracted from triplicate ST or SWT microcosm experiments, were first analyzed by $16 \mathrm{SrDNA}$ PCRdenaturing gradient gel electrophoresis techniques (data not shown) to assess the variability of the bacterial community structure between triplicates (denaturing gradient gel electrophoresis and pyrosequencing focused on the same 16SrDNA region). As denaturing gradient gel electrophoresis profiles from triplicate microcosms showed $>95 \%$ similarity, the respective DNA samples were mixed in equal proportions to reach a final amount of $10 \mu \mathrm{g}$. Composite DNA was added to a CsTFA (Amersham Pharmacia Biotech, Piscataway, NJ, USA) Tris-EDTA solution (final density 1.75). Centrifugation parameters were $140000 \mathrm{~g}$ for $72 \mathrm{~h}$ at $20^{\circ} \mathrm{C}$. Density gradients were fractionated and DNA in each fraction was quantified using the Quant-IT PicoGreen dsDNA Reagent kit (Molecular Probes, Eugene, OR, USA). Density fractions were pooled together to obtain one heavy and one light DNA density fractions. Every fraction was precipitated, ethanol washed, dissolved in nuclease-free water and stored at $-20^{\circ} \mathrm{C}$. An aliquot of each fraction was submitted to isotopic analysis (IRMS) to ascertain the degree of ${ }^{13} \mathrm{C}$ isotopic enrichment in the DNA. Isopycnic centrifugation and fractionation is detailed in Supplementary Information.

\section{Bar-coded pyrosequencing}

Total DNA extracted from soil sampled at the end of day 16 in CT and WT microcosms, and DNA 
purified from light and heavy density fractions of ST and SWT microcosms, were submitted to pyrosequencing (Roesch et al., 2007). Basically, the V3, V4 and V5 portion of the $16 \mathrm{~S}$ small-subunit ribosomal gene (position 341-907; Escherichia coli numbering) was amplified using a $341 \mathrm{~F}$ (5'-CCTACG GGAGGCAGCAG-3') and 907R primer (5'-CCGTCAA TTCCTTTGAGTTT- ${ }^{\prime}$ ) set associated with amplification fusion primers containing a directional Titanium Primer at the $5^{\prime}$ end of the oligonucleotide and a 10-bp MID (Multiplex IDentifier) sequence. Purified amplicons were fluorometrically quantified as previously described and equal amounts of each sample were combined in a single tube and transferred to a Roche FLX 454 pyrosequencing machine. Amplification details, as well as sequence quality filtering and OTU definition, are given in Supplementary Information.

Principal component analysis (PCA) was performed on a variables $\times$ samples table, where variables were families characterized by an abundance superior to $0.1 \%$ of the total number of sequences (6 samples $\times 20000$ sequences $=120000$ ). XLSTAT (Addinsoft SARL, Paris, France) was used for this analysis.

\section{Nucleotide sequence accession number}

The nucleotide sequences determined in this study have been deposited in the GeneBank database. Accession numbers are comprised between FQ670205 and FQ790206.

\section{Results}

\section{Earthworms}

All except one $P$. corethrurus survived until their removal at day 16 of the experiment. The biomass of all earthworms increased, especially when soil was amended with straw (data not shown). At day 16, worms released $15 \mu \mathrm{g}$ C- $\mathrm{CO}_{2}$ per hour per individual, which was $12 \%{ }^{13} \mathrm{C}$-enriched. The worm's respiration rate was considered to be stable along the incubation time and values were removed from overall $\mathrm{CO}_{2}$ and ${ }^{13} \mathrm{CO}_{2}$ respiration data in appropriate treatments to focus on the earthworm effect on the microbial-linked respiration.

Soil respiration, wheat residues mineralization and $P E$ At day 0 of ST experiment, wheat residue mineralization and $\mathrm{PE}$ were at their maximal levels with values of 2.8 and $7.7 \mu$ g C-CO ${ }_{2}$ per hour gram of soil mineralized, respectively (Figure 1). At this point of the SWT treatment, earthworms had not affected straw mineralization yet, while soil respiration was three times higher in the presence of earthworms. This discrepancy impacts upon the accuracy of the calculation of the PE, although the difference is not statistically significant. The extra $\mathrm{CO}_{2}$ release may originate from the earthworm gut soil content.

In the CT experiment, soil respiration rate was quite low and relatively stable throughout the

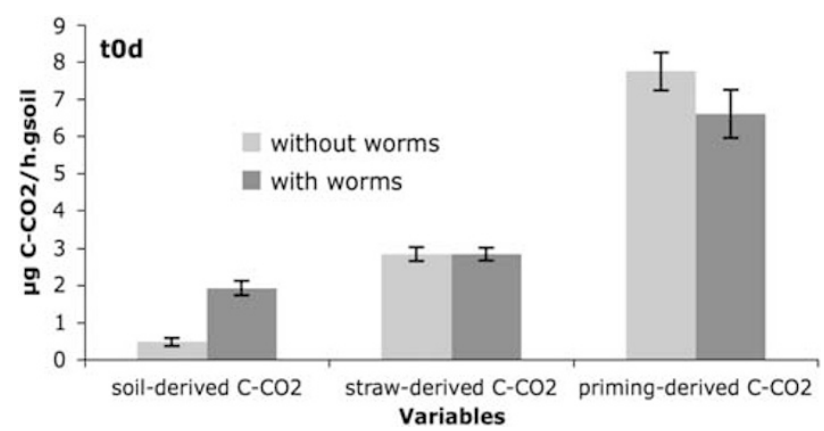

Figure $1 \mathrm{C}-\mathrm{CO}_{2}$ evolution rate from the different origins (soil basal respiration, straw mineralization and straw-induced PE) at the beginning of the experiment (day 0).
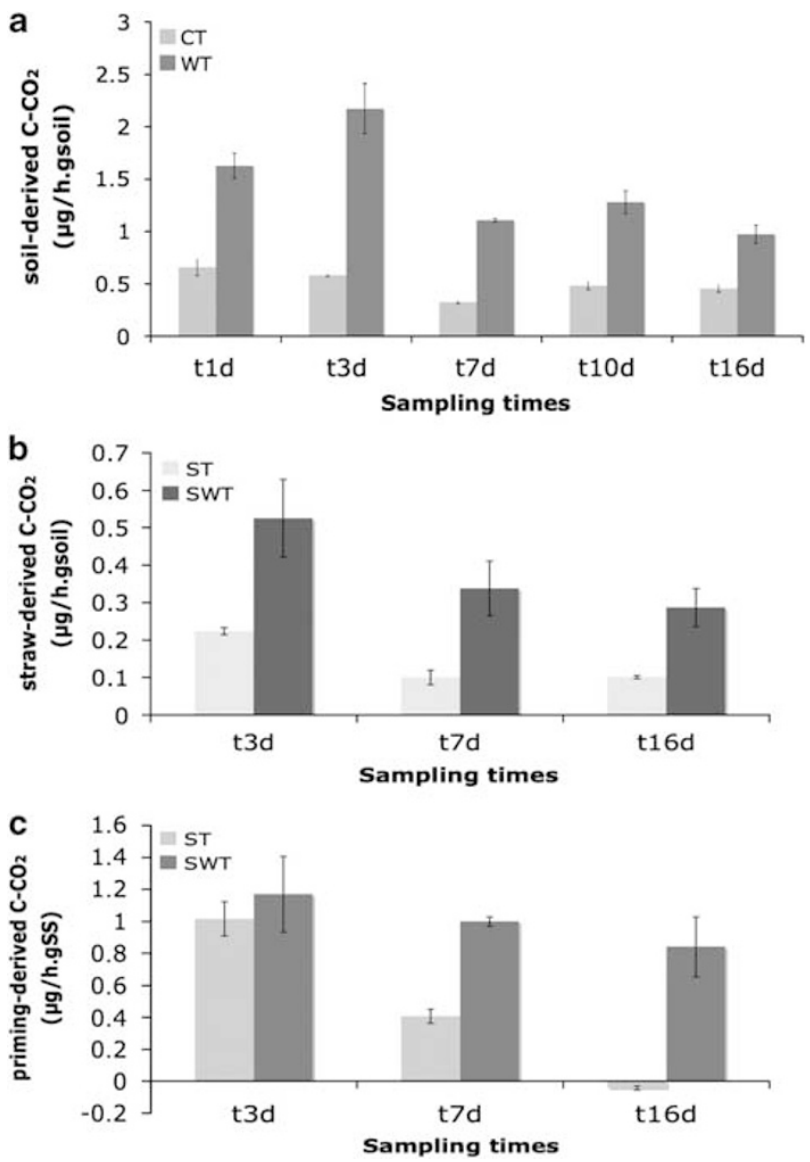

Figure 2 C- $\mathrm{CO}_{2}$ evolution rate from: (a) total soil respiration measured in the CT and the WT treatments along the 16 days of incubation; (b) straw mineralization measured in the ST and the SWT treatments along the 16 days of incubation; (c) strawinduced PE calculated from the ST and SWT treatments measurements (see Materials and methods section) along the 16 days of incubation.

incubation period, with a mean value of $0.50 \pm 0.11 \mu \mathrm{g} \quad \mathrm{C}_{-} \mathrm{CO}_{2}$ per hour per gram soil (Figure 2a). In the WT experiment, soil respiration was significantly stimulated throughout the experimental period. Maximal earthworm stimulation of soil respiration rate $(\times 3.9)$ was observed on day 3 of incubation. 
The straw mineralization rate decreased during the experimental period. Despite the fact that earthworms stimulated wheat mineralization by a mean factor of 2.6, the time-dependent pattern of the mineralization rate was basically similar to the one observed in the ST experiment (Figure 2b). We calculated (including day 0 data) that $7.4 \%$ of the residue was mineralized at day 16 in the WT treatment compared with $11.5 \%$ in the SWT.

PE rapidly decreased with time in the ST experiment (Figures 1 and 2c), even becoming slightly negative at day 16 . The time decrease in strawinduced $\mathrm{PE}$ was decelerated in the presence of earthworms (Figure 2c). From day 3 to day 16, worms increased PE by a mean factor of over 2.7. Moreover, the calculated extra carbon mineralized under the influence of wheat straw addition accounted for $2.6 \%$ of the soil organic carbon content at day 16 in the WT treatment and 3.6\% in the SWT.

Figure 3 shows the time-dependent evolution of the $I$ index, reflecting the effect of earthworms on soil respiration, straw mineralization and PE. The

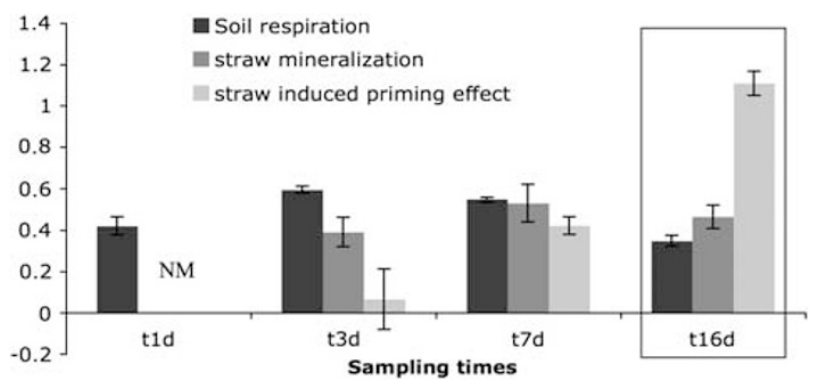

Figure 3 Time evolution of an index, derived from the RII index (Armas et al., 2004), varying between -1 and +1 and centered on 0 , reflecting the earthworm effect on soil respiration, straw mineralization and straw-induced PE. indices follow a similar time-dependent pattern, while the maximal earthworm effect occurred at different times depending on the targeted variable: after 3 days for soil respiration, 7 days for straw mineralization and 16 days for PE.

\section{Distribution of bacterial taxa among samples}

Taxonomic composition of bacteria represented in the DNA were investigated using ribosomal 16S gene sequencing. Each sample generated a set of 20000 clean sequences. Rarefaction curves (Supplementary Figure S2), corresponding to the different sets of sequences, are in exponential phase for the species (97\% similarity) and the genera phylogenetic levels (95\%). Consequently, results were derived for the phylum and the family phylogenetic levels because $90 \%$ and $82 \%$ similarity curves were the closest to the plateau phase.

For the CT experiment, almost $20 \%$ of the sequences could not be classified below the domain level (Table 1). This percentage declined in other treatments, while a simultaneous increase was observed in the percentage of sequences that cannot be classified below the family level (data not shown). Eighteen phyla were identified from the classifiable sequences, but only eight, displaying a relative abundance larger than $1 \%$ in at least one of the six samples analyzed, are presented in Table 1. The three most abundant phyla in the CT experiment were Proteobacteria $(31.1 \%)$, Acidobacteria $(20.7 \%)$ and Actinobacteria (17.2\%). Proteobacteria were dominated by the $\alpha$-subclass $(19.3 \%$ of the total sequences). The worm effect on each phylum was assessed by calculating the ratio between the percentages in the WT and CT sets. Similar ratios were calculated to assess the straw effect: $\left(\mathrm{ST}^{12} \mathrm{C}+\mathrm{ST}^{13} \mathrm{C}\right) / 2 \mathrm{CT}$. The combined effect of straw and worms (in SWT) was calculated in a similar

Table 1 Relative abundance of phyla and proteobacterial classes for each soil library

\begin{tabular}{|c|c|c|c|c|c|c|c|c|c|c|c|}
\hline Phylum & $\begin{array}{l}C T \\
(\%)\end{array}$ & $\begin{array}{l}W T \\
(\%)\end{array}$ & $\begin{array}{c}S T^{12} C \\
(\%)\end{array}$ & $\begin{array}{c}S T^{13} C \\
(\%)\end{array}$ & $\begin{array}{c}S W T^{12} C \\
(\%)\end{array}$ & $\begin{array}{c}S W T^{13} C \\
(\%)\end{array}$ & $\begin{array}{l}\text { Worms } \\
\text { effect }\end{array}$ & $\begin{array}{l}\text { Straw } \\
\text { effect }\end{array}$ & $\begin{array}{c}\text { Straw+worm } \\
\text { effect }\end{array}$ & $S T^{13} C /{ }^{12} C$ & $S W T^{13} C /{ }^{12} C$ \\
\hline Unclassified domain & 19.64 & 13.33 & 17.63 & 13.97 & 10.49 & 6.49 & 0.67 & 0.80 & 0.20 & 0.79 & 0.61 \\
\hline Actinobacteria & 17.18 & 13.07 & 26.34 & 28.87 & 19.06 & 20.03 & 0.76 & 1.61 & 1.14 & 1.10 & 1.05 \\
\hline Acidobacteria & 20.72 & 15.42 & 16.28 & 10.64 & 7.86 & 6.84 & 0.74 & $\overline{0.64}$ & 0.35 & 0.65 & 0.87 \\
\hline Proteobacteria & 31.08 & 34.12 & 32.77 & 40.05 & 28.07 & 28.55 & 1.10 & 1.17 & 0.91 & 1.22 & 1.02 \\
\hline$\alpha$-Proteobacteria & 19.28 & 18.10 & 23.70 & 21.36 & 18.16 & 11.75 & 0.94 & 1.16 & 0.78 & 0.90 & 0.65 \\
\hline$\delta$-Proteobacteria & 5.11 & 6.29 & 3.42 & 4.62 & 3.30 & 7.62 & 1.23 & 0.78 & 1.07 & 1.35 & 2.31 \\
\hline$\gamma$-Proteobacteria & 3.73 & 3.15 & 2.22 & 3.37 & 1.16 & 1.64 & 0.84 & 0.74 & 0.38 & $\overline{1.52}$ & $\overline{1.41}$ \\
\hline$\beta$-Proteobacteria & 1.85 & 5.01 & 1.73 & 8.58 & 4.07 & 6.10 & $\underline{2.70}$ & $\underline{2.78}$ & $\underline{2.74}$ & 4.97 & 1.50 \\
\hline Firmicutes & 0.51 & 1.09 & 0.50 & 0.34 & 0.98 & 0.25 & 2.12 & 0.82 & 1.19 & 0.69 & 0.25 \\
\hline Bacteroidetes & 1.91 & 16.27 & 2.67 & 3.93 & 28.36 & 35.72 & $\overline{8.52}$ & 1.72 & 16.78 & 1.47 & 1.26 \\
\hline Gemmatimonadetes & 2.54 & 1.03 & 1.16 & 1.14 & 0.24 & 0.41 & $\overline{0.40}$ & $\overline{0.45}$ & 0.13 & 0.98 & 1.69 \\
\hline Verrucomicrobia & 2.69 & 4.54 & 0.95 & 0.06 & 2.68 & 1.36 & 1.69 & 0.18 & 0.75 & 0.06 & 0.51 \\
\hline Planctomycetes & 1.77 & 0.47 & 0.31 & 0.31 & 0.86 & 0.13 & $\overline{0.27}$ & 0.17 & 0.28 & 1.02 & 0.15 \\
\hline
\end{tabular}

Abbreviations: CT, control; ST, straw-amended soil; SWT, combination of ST and WT; WT, worm-inoculated soil.

Worms effect corresponds to the ratio WT/CT; straw effect corresponds to $\left(\mathrm{ST}^{12} \mathrm{C}+\mathrm{ST}^{13} \mathrm{C}\right) / 2 \mathrm{CT}$ and straw+worms effect corresponds to $\left(\mathrm{SWT}^{12} \mathrm{C}+\mathrm{SWT} \mathrm{T}^{13} \mathrm{C}\right) / \mathrm{CT}$. Repartition of phyla and proteobacterial classes between functional fractions is assessed by ratio between ${ }^{13} \mathrm{C} /{ }^{12} \mathrm{C}$, for $\mathrm{ST}$ and SWT modalities. Underlined bold values show noticeable effect described in the text. 


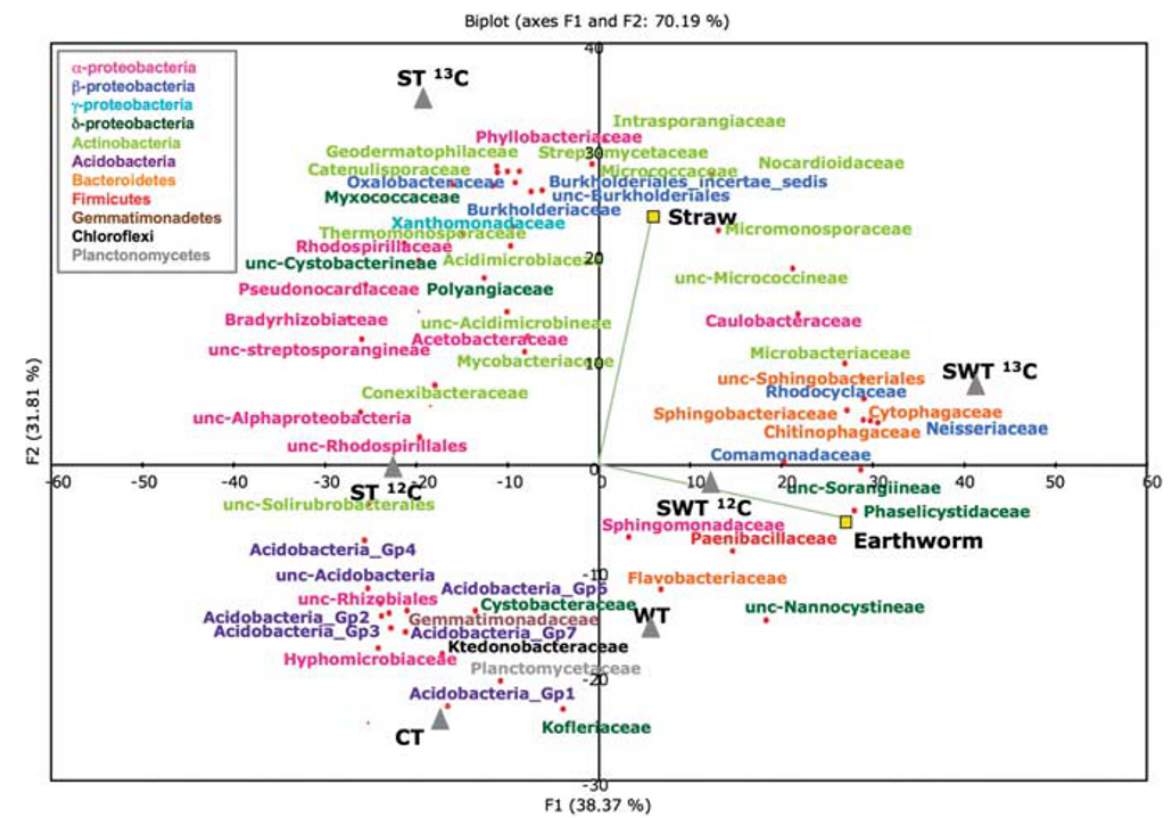

Figure 4 Biplot representation of the PCA performed on the composition of the six samples, submitted to pyrosequencing, in 59 bacterial families or phylogenetic groups. The correlation circle of variables has been superposed to the PCA plot. Family names are colored in function of their phylum origin.

manner: $\left(\mathrm{SWT}{ }^{12} \mathrm{C}+\mathrm{SWT} \mathrm{T}^{13} \mathrm{C}\right) / 2 \mathrm{CT}$. The presence of straw mainly promoted the $\beta$-proteobacteria $(\times 2.8)$, Bacteroidetes $(\times 1.7)$ and Actinobacteria $(\times 1.6)$, while worms promoted the Bacteroidetes $(\times 8.5)$, $\beta$-proteobacteria $(\times 2.7)$, Firmicutes $(\times 2.1)$ and Verrucomicrobia $(\times 1.7)$. The highest combined effect (SWT) was observed for the Bacteroidetes phylum with a stimulation factor of almost 17 . To observe the effect of worms on the partition of taxa among the functional fractions, the ratio of the percentages of phyla composing ${ }^{13} \mathrm{C}$ and ${ }^{12} \mathrm{C}$ fractions were also calculated for the ST and SWT sequences sets. At the phylum level, no drastic effect of worms on this ratio could be observed. However, when focusing on the Proteobacteria, worms mainly reduced the proportion of the $\beta$-proteobacteria in the ${ }^{13} \mathrm{C}$ fraction $\left({ }^{13} \mathrm{C} /{ }^{12} \mathrm{C}=1.5\right)$ compared with the ST sequences set $\left({ }^{13} \mathrm{C} /{ }^{12} \mathrm{C}=5.0\right)$ and simultaneously increased those of the $\delta$-proteobacteria (Table 1).

Straw and/or worm effects on the bacterial structure and diversity of non-labeled and ${ }^{13} \mathrm{C}$ labeled community fractions have also been observed at the family level (Supplementary Table S1). Forty families showed abundances superior to $0.1 \%$ of the total number of sequences $(120000)$. The elimination of rare phylogenetic groups avoided the presence of zero values into the (samples $\times$ variables) table, which is not suitable for the PCA (Legendre and Legendre, 1998). The 13 most abundant groups of organisms, which could not be classified below the order level, were also included in the analysis, as well as the six different groups of Acidobacteria. Wheat straw amendment strongly increased (that is by a factor $>5$ ) the abundance of bacteria belonging to 11 phylogenetic groups (from the 59 retained in our analysis), which represented $9 \%$ of the number of sequences of the $\mathrm{ST}^{13} \mathrm{C}$ and $2 \%$ of the $\mathrm{ST}^{12} \mathrm{C}$. The worms alone stimulated nine groups, representing $19 \%$ of the sequences obtained from WT. Seventeen phylogenetic groups were strongly stimulated by the combination of straw and worms, representing $44 \%$ and $31 \%$ of the sequences in the $\mathrm{SWT} \mathrm{T}^{13} \mathrm{C}$ and $\mathrm{SWT}^{12} \mathrm{C}$, respectively.

The biplot of the PCA for all bacterial groups and straw vs worm treatments is given in Figure 4 . The $x$ axis and $y$ axis explain $38.4 \%$ and $31.8 \%$ of the variability, respectively. Including the worm density and straw quantity as supplementary quantifiable variables revealed that worms drive variability on the $x$ axis, while straw drives that on the $y$ axis. The CT appeared to be mostly populated by Acidobacterial groups, Gemmatimonadaceae, Ktedonobacteriaceae, Plantomycetaceae and a few other families of $\alpha$ - (unclassified rhizobiales and Hyphomicrobiaceae) and $\delta$-proteobacteria (Cystobacteraceae and Kofleriaceae). Straw amendment alone promoted the development of many families of Actinobacteria, mainly from the Actinomycetales order, and $\alpha$-proteobacteria. Members of these groups, which cannot be classified below the order level, were more represented in the ${ }^{12} \mathrm{C}\left(\mathrm{ST}^{12} \mathrm{C}\right)$ DNA fraction than in the ${ }^{13} \mathrm{C}\left(\mathrm{ST}^{13} \mathrm{C}\right)$ one. The $\mathrm{ST}^{13} \mathrm{C}$ was also strongly populated by several families of the $\beta$-proteobacteria, mainly belonging to the Burkholderiales order. The presence of worms also promoted within the ${ }^{13} \mathrm{C}$-enriched DNA fraction $\left(\mathrm{SWT}^{13} \mathrm{C}\right)$ two families from the $\beta$-proteobacteria 


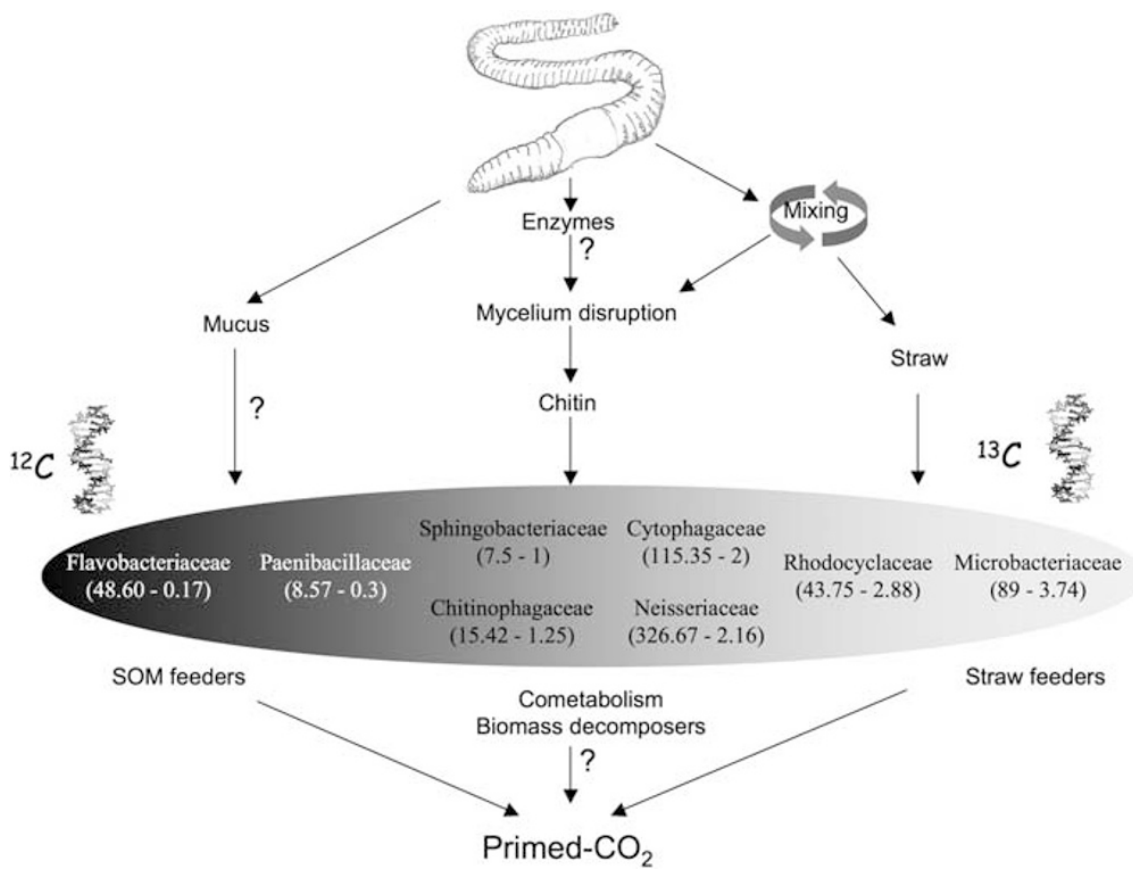

Figure 5 Conceptual scheme summarizing the hypotheses drawn from the study about the different processes used by earthworm to promote the activity of certain bacterial families and increase the SOM mineralization. Below each family name is indicated under brackets the 'straw + earthworm effect' factor (Supplementary Table S1), followed by the repartition of the representatives between ${ }^{13} \mathrm{C}$ and ${ }^{12} \mathrm{C}$ fractions in SWT treatments (Supplementary Table S1; ratio $\mathrm{SWT}^{13} \mathrm{C} / \mathrm{SWT}^{12} \mathrm{C}$ ).

(Neisseriaceae, Rhodocyclaceae), which were different from those observed in the $\mathrm{ST}^{13} \mathrm{C}$ sample, while one family (Commamonadaceae) was particularly present in the non-enriched fraction $\left(\mathrm{SWT}^{12} \mathrm{C}\right)$. The development of the Cytophagaceae family, belonging to the Bacteroidetes phylum, was stimulated by earthworms in the SWT ${ }^{13} \mathrm{C}$ DNA fraction. In contrast, the Flavobacteriaceae were highly present in the $\mathrm{SWT}^{12} \mathrm{C}$ fraction. The Sphingobacteriaceae and the Chitinophagaceae were also strongly favored, but were equally distributed in both DNA fractions. Several $\delta$-proteobacterial families from the Sorangiineae order were also promoted in the $\mathrm{SWT}^{13} \mathrm{C}$ as well as the Sphingomonadaceae and the Caulobacteraceae from the $\alpha$-proteobacteria. The Paenibacillaceae, from the Firmicute phylum, were promoted and mostly distributed in the unlabeled DNA fraction.

\section{Discussion}

It is widely held that every time FOM, microorganisms and SOM are combined in 'suitable' conditions, a PE event can potentially occur. However, the microorganisms that promote this event remain unknown and the 'suitable' conditions still need to be defined. In our study, earthworms significantly increased SOM mineralization.

This increase was accompanied by changes in the composition of bacterial communities composing both functional fractions: (i) the populations involved in labeled residue decomposition $\left({ }^{13} \mathrm{C}-\right.$ DNA-enriched: FOM feeders) and (ii) the populations exclusively involved in SOM mineralization $\left({ }^{12} \mathrm{C}-\mathrm{DNA}\right.$ : SOM feeders). We, therefore, discussed how such modifications would generate an increase in SOM mineralization. Hypotheses drawn from our data are summarized in Figure 5.

How do earthworms affect SOM feeders?

Earthworms strongly promoted the growth of several bacterial families (Flavobacteriaceae and Paenibacillaceae), which (in the presence of straw) were mostly represented in sequences derived from ${ }^{12} \mathrm{C}$-DNA. Those were, therefore, not involved in straw mineralization and likely not in indigenous particulate organic matter mineralization either. Lavelle et al. (1994) have proposed the so-called 'sleeping beauty' paradox, according to which earthworms would generate a PE via the mobilization of dormant microbial biomass by the addition of gut mucus. The gut mucus is a quite labile and nitrogenrich source of energy (C:N around 6; Brown et al., 2000), which then would likely activate fast-growing microbial species (r-strategy) (Fontaine et al., 2003; Blagodatskaya and Kuzyakov, 2008). This is coherent with our observations as Flavobacteriaceae (Bacteroidetes phylum) and Paenibacillaceae (Firmicutes phylum) have high 16S rRNA gene copy numbers (between 6 and 12), which is a characteristic of r-bacteria (http://ribosome.mmg.msu.edu/ rrndb/search.php). Those organisms are known to 
degrade polycyclic aromatic hydrocarbons and other xenobiotics (Bodour et al., 2003; Xu et al., 2010) and can thus be considered as potential degraders of complex SOM. But as the mucus is nitrogen-rich, why do these microbes expend energy degrading costly SOM? One can hypothesize that phosphorus availability will be a main driver in the $\mathrm{PE}$ in Ferralsols. Indeed, Ferralsols are highly depleted in readily available phosphorous, and it has been shown previously that $P$. corethrurus decreases the soil organic $\mathrm{P}$ and generates available-P content, suggesting that earthworms could be an important component of the $\mathrm{P}$ cycle in Ferralsols (ChapuisLardy et al., 1998, 2010; Patron et al., 1999).

How do earthworms impact FOM feeders?

While straw amendment alone appeared to increase global microbial activities without any drastic changes in the bacterial community structure, the presence of earthworms strongly promoted a few families, which dominated the bacterial community. Cytophagaceae (Bacteroidetes), Rhodocyclaceae and Neisseriaceae ( $\beta$-proteobacteria), which were abundant in the ${ }^{13} \mathrm{C}$-enriched fraction, are known to contain cellulose-degrading members (Yang et al., 2005; Weon et al., 2008; Wilson, 2009), while Sphingobacteriaceae, especially the Mucilaginibacter genus (Bacteroidetes), well represented in both ${ }^{13} \mathrm{C}$ - and ${ }^{12} \mathrm{C}$-enriched fractions, are often associated with the ability to hydrolyze pectin, xylan and other hemicelluloses (Pankratov et al., 2007). The fact that all of these phylogenetic groups are represented in both the ${ }^{13} \mathrm{C}$-enriched- and the ${ }^{12} \mathrm{C}$-DNA fractions (with a ${ }^{13} \mathrm{C} /{ }^{12} \mathrm{C}$ ratio between 1 and 4; see Figure 5) suggests that they are FOM and SOM feeders and therefore have generated some PE by a co-metabolism process (Fontaine et al., 2003). Earthworm activity prolonged the $\mathrm{PE}$ till the end of the experiment, while at the same time, we observed a negative PE in the straw treatment. Many Acidobacteria and $\alpha$-proteobacteria, which dominated the CT treatment, showed about one third of their representatives in the ${ }^{13} \mathrm{C}$-labeled fraction of the ST treatment. Based on the low 16S gene copy number of those phylogenetic groups (between 1 and 3), those organisms are slow-growing microbes that might be regular SOM feeders, feeding on the recalcitrant part of the straw that is left unused by faster-growing microbes, which used the more labile components (Fontaine et al., 2003). Therefore, earthworms appeared to prolong the short-term PE by promoting microorganisms (Bacteroidetes) that share some hybrid characteristics, being both medium to fast growers and endowed with specialized catabolic capabilities. Such organisms could be classified as 'decomposers' according to the definition of Moorhead and Sinsabaugh (2006), or as L-strategists according to Panikov (2010). A recent study, in which $16 \mathrm{~S}$ pyrosequencing has been performed on 88 soil samples from multiple areas of the United States, has shown that the Bacteroidetes phylum is sensitive to low $\mathrm{pH}$ (Lauber et al., 2009). The soil of the present study was acidic, but it is well known that $\mathrm{pH}$ is buffered during the earthworm gut transit (Barois and Lavelle, 1986).

How do earthworm impact biomass decomposers? In the present study, many of the bacterial families that were strongly promoted by earthworms are known to be chitinolytic organisms (Chitinophagaceae, Cytophagaceae, Neisseriaceae and Microbacteriaceae). This suggests a release of chitin, which is the main constituent of fungal skeleton. Many studies have reported that earthworms reduce microbial biomass, which leads to the hypothesis that earthworms consume microorganisms as a main part of their diet (Brown, 1995; Chapuis-Lardy et al., 2010). Some earthworms even display their preferences for fungal species feeding on labile carbon, compared with fungal species decomposing recalcitrant organic matter such as lignin (Moody et al., 1995; Bonkowski et al., 2000). It is thought that fungal hyphae are disrupted during the gut passage (Butenschoen et al., 2007). Correspondingly, $P$. corethrurus is known to produce chitinase (Brown et al., 2000).

The first hypothesis is that part of the registered increase in ${ }^{13} \mathrm{CO}_{2}$ and ${ }^{12} \mathrm{CO}_{2}$ originated from the bacterial consumption of the fungal biomass, which grew on straw and was therefore partly ${ }^{13} \mathrm{C}$-enriched. On the other hand, chitin is a N-rich polymer ( $\mathrm{C}: \mathrm{N}=7$ ), which cannot be metabolized by true r-strategists devoid of specific enzymes, and could be a good primer to stimulate SOM mineralization in a context of $\mathrm{P}$ limitation. This has to be proven by measuring chitinase activity as well as fungal biomass in the different treatments.

\section{Conclusion and outlooks}

We have shown that earthworms can strongly stimulate FOM and SOM mineralization in a tropical soil and that this stimulation can be linked to changes in the bacterial community structure. Our results suggest that earthworms can increase SOM mineralization by promoting a small number of bacterial groups that are characterized by medium to fast growth rates and specialized catabolic capabilities. Promotion of these microorganisms can result from (i) the availability of labile gut mucus, (ii) changes in soil physicochemical parameters during gut transit and/or (iii) of the degradation of fungal biomass and the liberation of chitin (Figure 5). Most of those populations seem to cometabolize FOM and SOM. Regarding the context of strong P depletion in Ferralsol, we hypothesize that one of the main drivers of $\mathrm{PE}$ is the conversion of organic phosphorus stored in SOM into readily available phosphorous accessible to microorganisms. Such a hypothesis has now to be proven and 
our observations to be extended to other soils and earthworm species belonging to different functional categories such as compacting and decompacting species (Blanchart et al., 1997).

\section{Acknowledgements}

This work has been partly funded by the French 'Agence Nationale pour la Recherche' (program Génomique) and the 'Institut National des Sciences de l'Univers' (Appel d'Offre EC2CO, program MicroBien). We thank K Lemoal and the LRI staff in Madagascar for their technical help for the experiment settlement. We also thank P Tillard (BPMP, INRA, Montpellier, Fr) for the IRMS analyses and V Santoni (BPMP, INRA, Montpellier, Fr) to give us the access to the ultracentrifuge and helping to use it.

\section{References}

Armas C, Ordiales R, Pugnaire FI. (2004). Measuring plant interactions: a new comparative index. Ecology 85: 2682-2686.

Barois I, Lavelle P. (1986). Changes in respiration rate and some physicochemical properties of a tropical soil during transit through Pontoscolex corethrurus (Glossoscolecidae, Oligochaeta). Soil Biol Biochem 18: $539-541$.

Beare MH, Reddy MV, Tian G, Srivastava SC. (1997). Agricultural intensification, soil biodiversity and agroecosystem function in the tropics: the role of decomposer biota. Appl Soil Ecol 6: 87-108.

Bernard L, Mougel C, Maron PA, Nowak V, Leveque J, Henault C et al. (2007). Dynamics and identification of soil microbial populations actively assimilating carbon from C-13-labelled wheat residue as estimated by DNA- and RNA-SIP techniques. Environ Microbiol 9: 752-764.

Bernard L, Maron PA, Mougel C, Nowak V, Leveque J, Marol C et al. (2009). Contamination of soil by copper affects the dynamics, diversity, and activity of soil bacterial communities involved in wheat decomposition and carbon storage. Appl Environ Microbiol 75: 7565-7569.

Blagodatskaya E, Kuzyakov Y. (2008). Mechanisms of real and apparent priming effects and their dependence on soil microbial biomass and community structure: critical review. Biol Fert Soils 45: 115-131.

Blanchart E, Lavelle P, Braudeau E, Le Bissonnais Y, Valentin C. (1997). Regulation of soil structure by geophagous earthworm activities in humid savannas of Côte d'Ivoire. Soil Biol Biochem 29: 431-439.

Bodour AA, Wang JM, Brusseau ML, Maier RM. (2003). Temporal change in culturable phenanthrene degraders in response to long-term exposure to phenanthrene in a soil column system. Environ Microbiol 5: 888-895.

Bonkowski M, Griffiths BS, Ritz K. (2000). Food preferences of earthworms for soil fungi. Pedobiologia 44: 666-676.

Bossuyt H, Six J, Hendrix PF. (2004). Rapid incorporation of carbon from fresh residues into newly formed stable microaggregates within earthworm casts. Eur J Soil Sci 55: 393-399.

Bossuyt H, Six J, Hendrix PF. (2006). Interactive effects of functionally different earthworm species on aggregation and incorporation and decomposition of newly added residue carbon. Geoderma 130: 14-25.

Brookes PC, Cayuela ML, Contin M, De Nobili M, Kemmitt SJ, Mondini C. (2008). The mineralisation of fresh and humified soil organic matter by the soil microbial biomass. Waste Manage 28: 716-722.

Brown GG. (1995). How do earthworms affect microfloral and faunal community diversity? Plant Soil 170: 209-231.

Brown GG, Barois I, Lavelle P. (2000). Regulation of soil organic matter dynamics and microbial activity in the drilosphere and the role of interactions with other edaphic functional domains. Eur J Soil Biol 36: 177-198.

Butenschoen O, Poll C, Langel R, Kandeler E, Marhan S, Scheu S. (2007). Endogeic earthworms alter carbon translocation by fungi at the soil-litter interface. Soil Biol Biochem 39: 2854-2864.

Chapuis-Lardy L, Brauman A, Bernard L, Pablo A, Toucet J, Mano M et al. (2010). Effect of the endogeic earthworm Pontoscolex corethrurus on the microbial structure and activity related to $\mathrm{CO}_{2}$ and $\mathrm{N}_{2} \mathrm{O}$ fluxes from a tropical soil (Madagascar). Appl Soil Ecol 45: 201-208.

Chapuis-Lardy L, Brossard M, Lavelle P, Schouller E. (1998). Phosphorus transformations in a Ferralsol through ingestion by Pontoscolex corethrurus, a geophagous earthworm. Eur J Soil Biol 34: 61-67.

Chapuis-Lardy L, Ramiandrisoa RS, Randriamanantsoa L, Morel C, Rabeharisoa L, Blanchart E. (2009). Modification of $\mathrm{P}$ availability by endogeic earthworms (Glossoscolecidae) in Ferralsols of the Malagasy Highlands. Biol Fert Soils 45: 415-422.

Coq S, Barthès BG, Oliver R, Rabary B, Blanchart E. (2007). Earthworm activity affects soil aggregation and soil organic matter dynamics according to the quality and localization of crop residues-an experimental study (Madagascar). Soil Biol Biochem 39: 2119-2128.

Egert M, Marhan S, Wagner B, Scheu S, Friedrich MW. (2004). Molecular profiling of 16S rRNA genes reveals diet-related differences of microbial communities in soil, gut, and casts of Lumbricus terrestris L (Oligochaeta: Lumbricidae). FEMS Microbiol Ecol 48: 187-197.

FAO. (1998). World Reference Base for Soil Resources. FAO, ISRIC, ISSS: Rome, pp 91.

Fontaine S, Mariotti A, Abbadie L. (2003). The priming effect of organic matter: a question of microbial competition? Soil Biol Biochem 35: 837-843.

Guenet B, Leloup J, Raynaud X, Bardoux G, Abbadie L. (2010). Negative priming effect on mineralization in a soil free of vegetation for 80 years. Eur J Soil Sci 61: 384-391.

Jenkinson DS. (1966). Studies on decomposition of plant material in soil 2. Partial sterilization of soil and soil biomass. J Soil Sci 17: 280-302.

Jones CG, Lawton JH, Shachak M. (1994). Organisms as ecosystem engineers. Oikos 69: 373-386.

Kuzyakov Y. (2010). Priming effects: interactions between living and dead organic matter. Soil Biol Biochem 42: 1363-1371.

Kuzyakov Y, Friedel JK, Stahr K. (2000). Review of mechanisms and quantification of priming effects. Soil Biol Biochem 32: 1485-1498. 
Lauber CL, Hamady M, Knight R, Fierer N. (2009). Pyrosequencing-based assessment of soil $\mathrm{pH}$ as a predictor of soil bacterial community structure at the continental scale. Appl Environ Microb 75: 5111-5120.

Lavelle P, Lattaud C, Trigo D, Barois I. (1994). Mutualism and biodiversity in soil. Plant Soil 170: 23-33.

Lavelle P. (1997). Faunal activities and soil processes: adaptive strategies that determine ecosystem function. Adv Ecol Res 27: 93-132.

Legendre P, Legendre L. (1998). Numerical Ecology, 2nd English edn Elsevier: Amsterdam.

Löhnis F. (1926). Nitrogen availability of green manures. Soil Sci 22: 253-290.

Moody SA, Briones MJI, Piearce TG, Dighton J. (1995). Selective consumption of decomposing wheat-straw by earthworms. Soil Biol Biochem 27: 1209-1213.

Moorhead DL, Sinsabaugh RL. (2006). A theoretical model of litter decay and microbial interaction. Ecol Monogr 76: 151-174.

Pankratov TA, Tindall BJ, Liesack W, Dedysh SN. (2007). Mucilaginibacter paludis gen. nov., sp. nov. and Mucilaginibacter gracilis sp. nov., pectin-, xylan- and laminarin-degrading members of the family Sphingobacteriaceae from acidic Sphagnum peat bog. Int J Syst Evol Micr 57: 2979-2979.

Panikov NS. (2010). Microbial ecology. In: Wang LK et al. (eds) Handbook of Environmental Engineering, Volume 10: Environmental Biotechnology. Springer
Science+Business Media, LLC: New York, NY, doi: 10.10007/978-1-60327-140-0_4.

Patron JC, Sanchez P, Brown GC, Brossard M, Barois I, Gutierrez C. (1999). Phosphorus in soil and Brachiaria decumbens plants as affected by the geophagous earthworm Pontoscolex corethrurus and P fertilization. Pedobiologia 43: 547-556.

Roesch LF, Fulthorpe RR, Riva A, Casella G, Hadwin AKM, Kent AD et al. (2007). Pyrosequencing enumerates and contrasts soil microbial diversity. ISME J 1: 283-290.

Speratti AB, Whalen JK. (2008). Carbon dioxide and nitrous oxide fluxes from soil as influenced by anecic and endogeic earthworms. Appl Soil Ecol 38: 27-33.

Weon HY, Kim BY, Yoo SH, Kwon SW, Go SJ, Stackebrandt E. (2008). Uliginosibacterium gangwonense gen. nov., sp nov., isolated from a wetland, Yongneup, in Korea. Int J Syst Evol Micr 58: 131-135.

Wilson DB. (2009). Evidence for a novel mechanism of microbial cellulose degradation. Cellulose 16: 723-727.

$\mathrm{Xu} \mathrm{L,} \mathrm{Teng} \mathrm{Y,} \mathrm{Li} \mathrm{ZG,} \mathrm{Norton} \mathrm{JM,} \mathrm{Luo} \mathrm{YM.} \mathrm{(2010).}$ Enhanced removal of polychlorinated biphenyls from alfalfa rhizosphere soil in a field study: the impact of a rhizobial inoculum. Sci Total Environ 408: 1007-1013.

Yang HC, Im WT, An DS, Park WS, Kim IS, Lee ST. (2005). Silvimonas terrae gen. nov., sp nov., a novel chitindegrading facultative anaerobe belonging to the 'Betaproteobacteria'. Int J Syst Evol Micr 55: 2329-2332.

Supplementary Information accompanies the paper on The ISME Journal website (http://www.nature.com/ismej) 